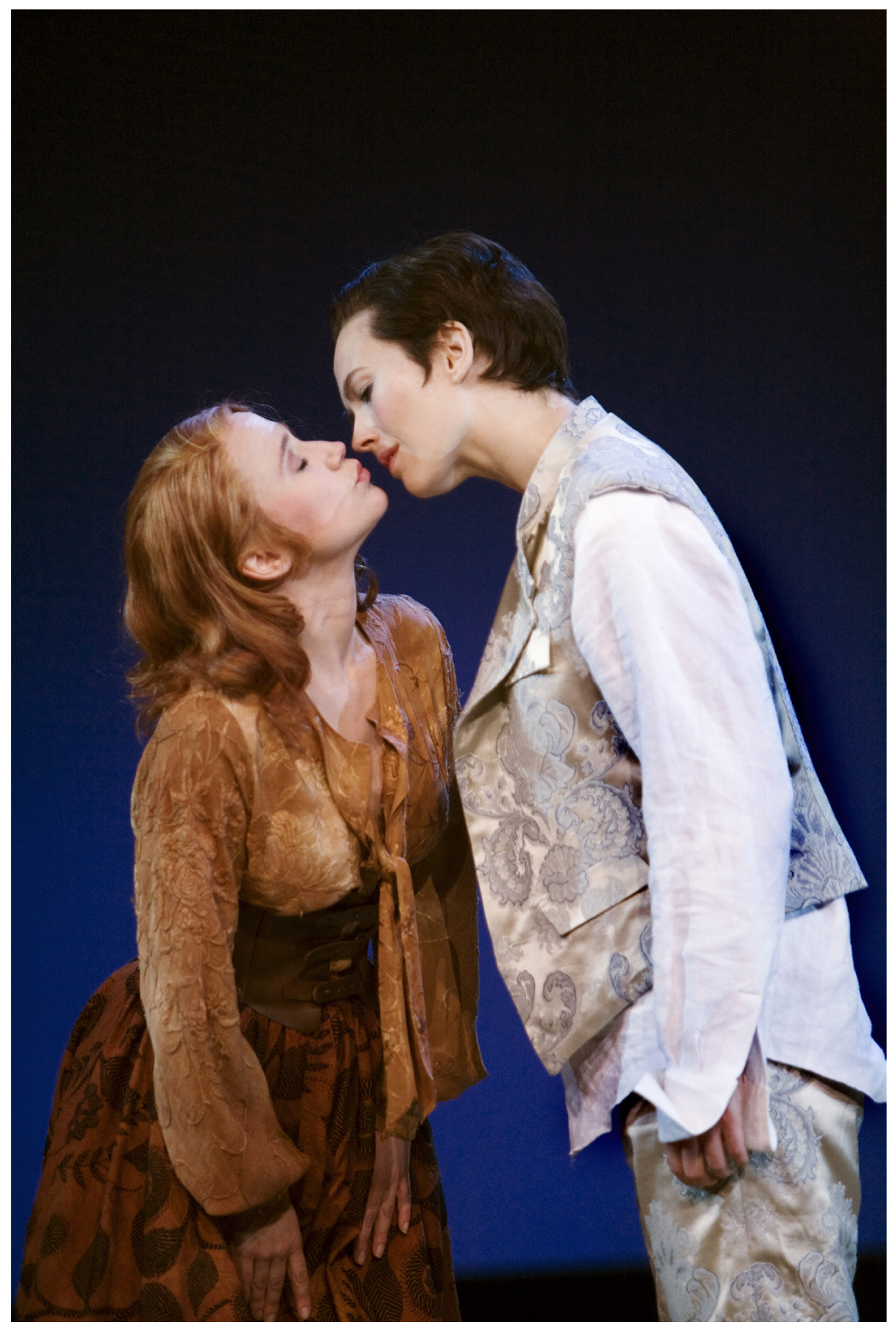

The Queen's Diadem (Carl Jonas Love Almqvist). Elin Klinga (Tintomara) and Anja Lundquist (Adolfine). Royal Dramatic Theatre, Stockholm, 2008. Photographer: Roger Stenberg. Copyright CC-BY-NC-ND, Royal Dramatic Theatre, Stockholm. 


\title{
6. Queer Tintomara: Ephemeral and Elusive Gender(s) in The Queen's Diadem
}

\author{
No one will find me, \\ I will find no one. \\ I smile at each one, \\ they all smile at me. \\ Tintomara's Song (QD, I34)
}

Transcending borders has been one of the key terms of queer theory. The prefix "trans" indicates the possibility of moving between different gender roles and sexual categories. This type of kinesis interests queer theorists, who aim at creating more flexible options for the heteronormative definitions of gender and sexuality. Ideas and practices that cross borders, however, are not limited to recent contemporary theorists; they also apply to a novelist of the Romantic period who delights in transformations and unforeseen encounters. One work in particular, The Queen's Diadem (Drottningens juvelsmycke), is considered a true gender classic of Swedish literature. The novel was written by Carl Jonas Love Almqvist (I793-I 866) in I 834 as the fourth installment in a series entitled Törnrosens bok (The Book of the Thorn Rose). Almqvist creates a theatrical fantasy world where boundaries are transcended. The Queen's Diadem also presents the intriguing figure of Azouras Lazuli Tintomara, an androgynous character loved by women and men alike, but who in fact does not love anyone apart from her mother. ${ }^{2}$

The Queen's Diadem forms an important bridge between the Romantic and the Postmodern eras as a work of literature, and for its gender thematics. Objects of desire shift according to the

How to cite this book chapter:

Rosenberg, Tiina 20I6. Queer Tintomara: Ephemeral and Elusive Gender(s) in The Queen's Diadem. In: Rosenberg, Tiina Don't Be Quiet, Start a Riot! Essays on Feminism and Performance. Pp. I I 8-I 49. Stockholm: Stockholm University Press. DOI: http://dx.doi.org/IO.I6993/baf.f. License: CC-BY 4.0 
ever-changing gender status of Tintomara. Examining aspects of Tintomara's androgyny, that is, her sexuality or asexuality, will show how the variability of her gender kindles a passion in others, and allows desire to blossom into a realm of possibilities.

\section{A queer interpretation}

A contemporary reading of The Queen's Diadem cannot help drawing attention to its queer potential. The foundation of the queer perspective is that the predominant culture is heteronormative, but not necessarily heterosexual. In the Western world a certain tension or ambiguity, perhaps also an uncertainty, exists between homophobia and homoerotics, and the issue of whether same-sex desire may only be limited to homosexuals. If such longing applies to everyone, heterosexual culture and its manifestations are hardly as clear-cut as one may assume: fragments of queer may be embedded. ${ }^{3}$

Queer has acquired multiple meanings over the past few decades. It is most commonly perceived as a synonym for lesbian, gay, bisexual, transgender, or queer (LGBTQ) identities, or as an umbrella term for a variety of non-heterosexual and non-normative gender statuses. However, queer has occasionally been applied to non-heterosexual phenomena that cannot be clearly labeled as LGBTQ. In these cases queer appears to internalize or allude to one or more of the above categories, sometimes in a confusing or incongruous manner. Queer has also been used to indicate forms of spectator perspectives, interpretations, works of art, cultural phenomena, and textual coding systems that fall outside the gender and sexual conceptions related to heterosexual or LGBTQ identities. Thus, the term queer may apply to anything beyond the traditional categories of gender and sexuality. ${ }^{4}$

Queer reading has its roots in the approach to literature that allows alternative interpretation. It leans toward the feminist tradition and is informed by lesbian and gay studies in the humanities. Nevertheless, queer interpretation is not entirely synonymous with classic feminist methodology, which does not hesitate to go against the grain in order to highlight inherent sexism - or, conversely, hidden feminist traits.

Queer interpretation goes a step further by juxtaposing itself to non-queer. However, its intention is not only to produce analyses of 
literary or other artistic works by non-straight authors and artists. Its theoretical starting point is that queer is at the nexus of culture, just as non-queer has been. Queer interpretation, therefore, must assume that queer has the potential to be present in all works of art. Queer readings may be applied to any text, film, theatrical performance, artwork, or product of popular culture, without the interpreter needing to cite queer as a prominent element in such work.

\section{Tintomara: The androgyne in literary study}

The Queen's Diadem takes place in Sweden in I792. An opera masquerade ball coincides with the assassination of "Theatre King" Gustav III of Sweden. The novel centers around the theft of a priceless royal gem. The curious and remarkably beautiful Tintomara, a dancer, is the protagonist who has stolen the jewel a diadem. However, unbeknownst to Tintomara, she also serves as Gustav III's decoy at the fatal opera masquerade. Tintomara is the half-sister of the heir apparent; Equerry Munck is supposedly her father. She is soon to be swept up in a political power struggle that erupts as a backlash to the king's murder. A pawn in the cunning scheme, Tintomara is ultimately shot by an assassin.

Desired by women and men alike, Tintomara comes between two sisters, Amanda and Adolfine, and their suitors, Captain Ferdinand and Major Clas Henrik. The recurrence in the novel of the five of spades and the five of hearts symbolizes the conflict. A case of mistaken identities entangles the two couples in a drama of jealousy enacted in a dream-like forest in northern Stockholm. The story has clear parallels to Mozart's operas Cosi fan tutte and Le nozze di Figaro. It culminates in a duel between Ferdinand and Clas Henrik.

The prominence of androgyny in The Queen's Diadem was noticed soon after the novel first appeared. The role gender plays is so apparent that omitting it from an analysis would almost be impossible. Nevertheless, the first person to study gender and sexuality in Almqvist's works to any extent was Karin Westman Berg, a women's studies pioneer, whose work established the foundation for gender-based Almqvist research in Sweden. ${ }^{5}$

The issue of androgyny is discussed early on in Johan Mortensen's I905 essay on the background of the Tintomara character. Mortensen sees French fairy tales and Matthew Lewis's 
classic Gothic novel The Monk (I796) as possible models for Tintomara. In the expanded I9I7 version of his study, Mortensen deals with the erotic and demonic features of The Queen's Diadem, drawing comparisons to another androgynous figure, Goethe's Mignon. Hans Hagedorn Thomsen continues this line of thought in a I970 analysis that aligns Tintomara with other androgynous literary characters. Thomsen emphasizes Tintomara's metaphysical nature: on the one hand she represents human striving toward an "ultimate goal," and on the other she embodies the creative process. Hagedorn Thomsen interprets Tintomara as a fiction within a fictitious world that is devoid of any socially significant incongruities with regard to gender. He highlights the central symbolism surrounding Tintomara: the ruby, the hermaphrodite, and the square room, which he construes as totality symbols. However, Olle Holmberg, who republished Almqvist's novel in I922, saw no meaningful link between the character of Tintomara and the androgynous musings of the German Romantics. Rather than having two genders, Tintomara, according to Holmberg, was genderless. He describes her as a "painted arabesque," a beautiful but hollow helix who loves no one and lives by no rules. ${ }^{6}$

A work that more clearly assesses the gender issue in The Queen's Diadem is Eva Adolfsson's article “Det androgyna skapandet: en Almqvistläsning” (The androgynous creation: An Almqvist reading), which considers alternate understandings of the text. Initially, the androgynous character may be seen as a metaphor for the masquerades played by society. However, such an interpretation, Adolfsson cautions, takes one nowhere. She then deals with the polarities of freedom and isolation, describing Tintomara as a hero/heroine of neither sex, but rather an amalgam of both female and male characteristics. Tintomara lives outside the laws of god and man; her home is a peaceful, non-verbal maternal sanctuary. ${ }^{7}$

Anna Cavallin has brought the interpretation of Almqvist a step closer to the gender studies of today. She examines the mercurial nature of Tintomara's make-up as an illustration of the social construction of gender. By polemicizing earlier research, Cavallin weighs questions of gender, body, and power, concluding that Tintomara's acting constitutes resistance. Tintomara refuses to take on a submissive status, and in the end she perishes. ${ }^{8}$ 
A queer interpretation of The Queen's Diadem have also been made by Laura Margaret Desertain in a 1982 dissertation that emphasizes the novel's same-sex desire and sums up Tintomara as a natural lesbian. A I 999 article by Eva Borgström cites desire and queer erotics as the main themes of the novel. For her, the singing voices of the four young members of the nobility constitute a symbolic scale that encompasses both female and male voices. She draws comparisons to Plato's Symposium as one of the foremost intertexts of The Queen's Diadem, and also compares Almqvist's novel to Diderot's Les bijoux indiscrets ( 1748 ). ${ }^{9}$

\section{Plato's Symposium and the myth of the androgyne}

When Tintomara is first mentioned in The Queen's Diadem, surgeons are have been ordered by the police to inspect her body in order to determine her "true" sex.

But certainly there must be something odd about this creature. The throat and the beginning of the chest, which I saw, were of a very pleasing, but strange structure, which seems to allow the former to be raised sometimes in conjunction with the contraction or hardening of the latter; on the contrary, at other times, the latter might be expanded, in conjunction with the diminution of the whole figure. (QD, 40-4I). ${ }^{\text {. }}$

Tintomara is said to try have sometimes tried to escape "with the caressing, appealing expression of a suffering siren," but "at other times the same person would assume, suddenly and with fiery pride, a note of resistance which might almost seem masculine" (QD, 4I). ${ }^{\text {I }}$ The surgeon's remarks are directed solely at Tintomara's chest, voice, and temperament; the reader is therefore not privy to any observations regarding her genitalia (QD, 4O-4I). ${ }^{\text {I2 }}$

Tintomara, referred to with Almqvist by the Swedish feminine personal pronoun bon (she) despite the character's androgyny, is in police custody for questioning when at least six socialites (women and men) commit suicide after falling hopelessly in love with her. Why, we wonder, should the police even care? Unable to arrive at any conclusion, the surgeons wonder how to classify Tintomara, or why she needs to be categorized in the first place. 
One of them offers the resigned comment, "The police don't seem to be able to tolerate one and the same individual being loved by all kinds of persons" (QD, 40). ${ }^{13}$ Here Almqvist's narrative shows its indebtedness to a conversation on love that took place almost 2,500 years ago.

Plato's Symposium is generally acknowledged to be the background to The Queen's Diadem. Same-sex eroticism was on a higher plane in the Symposium than heterosexual eroticism. For Plato, the love (eros) between two men was above the love of a woman and a man. The Symposium is a conversation that Plato is supposed to have heard about and recorded. In it, seven men, including Socrates, attend a banquet where they take turns discussing the principles of love.

In pursuit of its origins, Socrates presents as Plato's voice a myth about androgynies. In the beginning, the human body was not singular but dual. It had two faces, four arms, four legs, and two sets of genitals. "Man" was self-absorbed, closed off, harmonious, a perfect entity, a whole unto himself. However, he was so content enjoying his own company that he neglected his responsibilities towards the gods. This angered the gods, so they decided to reconfigure the human body and split it into two parts. Since that moment, each half has been searching the world, longing to reunite with its counterpart. ${ }^{14}$

According to this myth, which Socrates ascribes to a priestess named Diotima, the human being originally represented three genders simultaneously: male-male, female-female, and the third gender, androgyny, in which female and male were amalgamated. When this whole was divided in two, the genders we recognize were formed as female and male. Three genders thus became two. Or was it four, as Eva Borgström proposes? According to her, the answer depends on how one interprets the Symposium. ${ }^{\text {I5 }}$

The halves with male genitalia, whose former halves also had male genitalia, began searching for their lost male counterparts. Today, such individuals are referred to as gay males, a term with which neither Plato nor Aristotle were familiar. Individuals with female parts who had previously been one with another female half were the predecessors of lesbians. While Plato did not seem to think of women roaming the earth in search of their lost female 
half, he nevertheless referred to women loving other women as a familiar practice.

The third gender, the androgyne that was both female and male, was split into two types of heterosexual halves. The myth describes heterosexual love as we generally know it today as having its roots in the original androgynous (andros "man" and gyne "woman") human body, which for Plato, speaking through Socrates, represented a kind of gender deviation. Fully female and fully male humans thus searched for same-sex love upon being cloven in two. According to this interpretation, today's norms derive from the androgynous beings of a previous time, and the Platonic Socrates' same-sex beings also provide the template for deviations from those norms. ${ }^{16}$

Almqvist's surgeons attempted to discover why both women and men fell in love with Tintomara, although personally the surgeons seemed to have nothing against the idea in itself. The surgeon who supports the myth of the androgyne does not consider it a clear explanation (logos), but only a story (mythos) that provides some form of hesitant account for lack of a better explanation: "This thing about androgynies is something people have made up to find an explanation for what they don't understand" (QD, 43). ${ }^{17}$ The myth of the androgyne and the birth of love are presented in The Queen's Diadem as follows:

An androgyne was understood to be something strange, something mystical in fact. You see, the belief was - there are several reasons for believing this - that humans were originally created simply as human beings. Not man, not woman, but simply human being; do you understand, my friend? Still, I don't know whether "androgyne" should refer to a creature who is neither sex or both. The former seems extremely sad; the ancients have thought much about the latter. For in the latter case, my friend, there would be a whole, uniting the nature of both sexes in itself .... The ancients, who imagined the androgyne to be such a complete, self-sufficient, and, according to their ideas, blessed creature, added that it was precisely the fall of man, or at least an integral part of the fall, that the human being was cloven in two, fell apart into two sexes, whose destiny it would be to chase each other forever, to fortune or to misfortune. Through the division of the originally united human 
being, there developed two hemispheres instead of one sphere: two kinds of beings, man and woman; through this, my friend, the possibility of love (Eros) occurred, but also of discord (Eris). $(\mathrm{QD}, 42)^{\mathrm{I}}$

The passage above encompasses numerous themes from The Queen's Diadem. They are admittedly all based on Almqvist's interpretation of Plato. One example is the kinship between Eros and Eris. The novel is filled with love, jealousy, aggression, and dissonance. The themes of eroticism and violence go hand in hand, although this does not correspond to Plato's philosophy, as Borgström points out. She sees the myth of Eros depicted in a heterosexualized manner in Almqvist's novel. The narration only mentions the precursors of heterosexuals, but the bi-gendered body that spawned same-sex love is not named.

In Plato's thinking homoeroticism induces shifts in cultural values and political renewal because older men teach and inspire the younger male generation. Similarly, homoerotic desire acted as a driving force for youths seeking new information to foster their development and bring them closer to fulfilling their roles as purveyors of culture and pillars of society. Socrates only mentions female-to-female love on one occasion and as a matter of symmetry, as Page du Bois notes in Sappho is Burning. ${ }^{19}$ Such love is not given any significance other than the satisfaction or fulfillment it brings to the lovers. Although the Symposium mentions women, the thought of love and eroticism between them is excluded completely.

In addition to his allusions to the Symposium, Almqvist indicates elsewhere in the novel that androgyny can be perceived as a kind of perfect human form. An androgynous person, according to him, is a closed entity in which femininity and masculinity come together to form a flawless creature who, in addition, does not experience human erotic desires that others suffer from. An androgyne is the object of its own desire, a complete being who feels no sexual urge, as it already embodies everything. Passions that spawn pleasure and suffering are not the drawback they may be to other people.

The androgyne of Almqvist's novel can be seen either as suffering from a relentless and insatiable desire, or as immune from any sense of deprivation or craving. Both options would suit Tintomara. While Tintomara mourns for those whose lives she 
has ruined, she has no wish to be loved. At the end, she even begs: "Promise me, Georg, that you, at least, don't love me.... All the others love me; they wither, die, perish, break. . " (QD, I 62). ${ }^{20}$

The surgeons' discussion suggests that androgyny is a form of gender melancholy, and they wonder whether androgyne is female, male, or perhaps neither one of them. Melancholia may be present in the Symposium through its intermediate tragic state of the human when it has been divided but has yet to assume the gender(s) we recognize today. According to myth of eros that Socrates offers, the hunger for one's other half was so consuming that humans made do with whomever they could find, regardless of whether they were "female" or "male", and clung to them so fiercely that one or the other perished from thirst or hunger. The surviving being then found someone new to cling to, but his or her desire was never satiated because the human genitals were situated in the wrong location. Finally, when humankind threatened to become extinct, the gods stepped in and decided to relocate the genitals to their current place. This then allowed women and men to fulfill their desires, curb their longing, and reproduce. $^{2 \mathrm{I}}$

Melancholia, from the Greek melas (black) and khole (bile), is interpreted in Hippocratic medicine as a malady. According to ancient theory regarding bodily liquids, bile in copious amounts caused a heavy heart; that is, melancholia, and filled one's soul with gloom, weighing it down. However, melancholic despondency did not imply desperation or death. Instead, it also provided the seed for rebirth. Judith Butler, connecting gender melancholy to a heterosexual matrix that culturally denies the mourning of a homosexual love lost, writes:

What ensues is a culture of gender melancholy in which masculinity and femininity emerge as the traces of an ungrieved and ungrievable love; indeed, where masculinity and femininity within the heterosexual matrix are strengthened through the repudiations that they perform. In opposition to a conception of sexuality which is said to "express" a gender, gender itself is here understood to be composed of precisely what remains inarticulate in sexuality. ${ }^{22}$

Butler's notion of gender melancholy is based on the idea that heterosexuality naturalizes itself by insisting on the radical otherness 
of homosexuality. Heterosexual identities are purchased through a melancholic incorporation of the love that they disavow. For Butler, the man who insists upon the coherence of his heterosexuality will claim that he never loved another man, and hence never lost another man. The consequence is that the love attachment becomes subject to a double disavowal: a never having loved, and a never having lost. This "never-never" thus founds the heterosexual subject, as it were; it is an identity based upon the refusal to avow an attachment, hence, the refusal to grieve. ${ }^{23}$

\section{Tintomara: Fostered by the theatre}

Almqvist wrote several plays in the I83os. The Queen's Diadem, although a novel, contains a great many theatre-esque and theatrical traits. Theatre is also one of its central themes, and its text is notably rich in dialogue. The plot also embodies a meta-theatrical structure (a play within a play), which is connected to the general concept of theatrum mundi - the world as a stage in which life is role-playing and where masquerading belongs to life.

Ulla-Britta Lagerroth has analyzed the ways which theatricality may be tied to the written text. A text can be 'themed' by a theatre context and deal with matters relating to theatre: performances, fictitious actors, directors, and the like. Theatrical traits can be brought into a text formally or structurally through standard ways of representing theatre: dialogue, tableaus, demarcated performance and audience situations, or theatrical language, including gestural rhetoric. Characters may be used as metaphors or symbols, their lives partaking of the dynamics of the stage. A text may include several of these mechanisms. ${ }^{24}$

Tintomara is represented as having grown up in the theatre. Her mother is an actress and her father, Equerry Munck, is rumored to be Gustav III's proxy for the heterosexual obligations of marriage. As an actress, dancer, and androgyne, Tintomara plays a liminal role. A permanent half-status in terms of gender does not result in positive reactions from those she meets. Tintomara is also viewed warily because individuals with a two-fold gender identity fall outside "normal" social categories. In Vested Interests, Marjorie Garber suggests that suspicion is traditionally expressed toward 
individuals who disguise themselves or dress as someone else as part of their lives: actors, diplomats, transvestites, and spies. ${ }^{25}$

Theatricality does not only appear in exceptional scenes in The Queen's Diadem. It is also present in the novel's outbursts of emotions and the feelings of exaltation contained in its grand gestures, and can be seen in those characters who are performers on the stage of everyday life. This is apparent in tableau-like scenes that include melodramatic gestures typical of the theatre at that time.

The Queen's Diadem creates a meta-stage consisting of the volatile Tintomara and an epic storyline. Tintomara's stage is a tableau, a mise en abyme or internal mirror. It is an element introduced into narrative by another art form to reflect the theme of an entire text. This strategy may also include Tintomara's gender turnovers. Such theatralization has been widely used in the nineteenth-century English novels of Jane Austen, Charlotte Brontë, George Eliot, Charles Dickens, and William Makepeace Thackeray.

The philosophy of enjoyment was important to Almqvist. He believed that art should bring people pleasure, and that an author should not teach readers without also entertaining them. He maintains the dramatic tension of The Queen's Diadem by incorporating into the novel a complex model based on curiosity and anticipation that he borrowed from melodrama. Theatricality also allows for the exploration of gender and sexuality without creating a general sense of taking things too far. Thus, Almqvist could write freely about eroticism, a subject that novels, books of etiquette, and the rules of the church and society were silent about at the time. ${ }^{26}$

\section{Flight, volatility, and disguise}

Tintomara is taken advantage of by Ferdinand and Clas Henrik in their conspiracy against Gustav III. They give her the task of luring the King into the main hall of the Royal Opera House, where he is shot. After the King's assassination, the protagonists flee Stockholm to the forests of Kolmården. Distraught by the part their fiancés played in the murder, Adolfine and Amanda remain at their family estates in Östergötland. Meanwhile, Clas Henrik and Ferdinand are hiding only a few miles away, near the shores of 
Bråviken. Tintomara, using the name Lazuli, arrives in Kolmården cross-dressed as a man. The four young aristocrats all fall in love with this androgynous person and are slowly driven mad by their passion. During a key scene in the dark of night, the four youths advance toward Tintomara at a crossroads in Lindamot, each coming from a different direction.

Tintomara's voice stopped abruptly and her head jerked to one side, for her sharp eyes seemed to see something actually approaching, and it was as if all those to whom she was saying goodbye in her singing imagination came to say goodbye to her as well. She saw movement on the four roads; she saw something approaching simultaneously along the long, black lanes. It approached deliberately, silently, but identical on all four roads. On all four of them, it approached so carefully as if each one on its road did not want to be noticed by anything else. (QD, I70 ${ }^{27}$

This X-pattern recurs several times in the novel. Tintomara is like a mysterious vertex, towards which all passion and yearning is directed.

Tintomara flees love, but Baron Reuterholm, the power-hungry villain of the piece, arrives at the Stavsjö estate in Östergötland and blocks her escape. In the company of Reuterholm, Tintomara returns to the political grand stage in Stockholm. But would-be suitors in the capital also plague her. This wild and free doe-like character is to be tamed by Duke Charles, taken as his lover, and inured to the lavish boudoirs of the castle.

Nervertheless, once again Tintomara flees. She enlists as a musician in the Royal Swedish Army Band, then misbehaves during a parade. While being pursued by Reuterholm's spies, she violates military regulations and is sentenced to death. Following a lengthy deliberation, a mock execution is performed with empty rounds fired. After the smoke has cleared, it is revealed that Ferdinand has returned to Stockholm from Kolmården. Now taking his place as a member of the firing squad, he fires live rounds and kills Tintomara. We learn that he had previously shot Clas Henrik, and later is himself executed. Adolfine and Amanda, although they remain alive, go mad.

The heroines of plays and novels often cross-dress for a brief period when an enemy appears or danger threatens. Flight is a 
typical literary device for cross-dressing female literary characters. Since searching for a wronged love is often their object, masquerading as a man becomes a practical option. Gertrud Lehnert has stated that women do not cross-dress because of a longing for freedom or independence, but to resolve a problem that they can more effectively pursue if they present themselves as men. In male attire, women are able to gain access to a man's world. ${ }^{28}$

In The Queen's Diadem the flight motive is tied to Tintomara's impulsiveness and peculiarity. Volatility, androgyny, and "animality" are all intertwined in the novel. One surgical consultant links androgyny to bestiality, whereas another speaks of an animal coeleste, a divine animal:

The animal's way of being, instinctual life, demonstrates the harmonious, appealing picture of a creature totally in union with itself. You will be familiar with the theory of the mystics, about the animal coeleste? The aim of human beings, it is said, is in fact eventually to become nature once again, to become like an animal. $(\mathrm{QD}, 42-43)^{29}$

In medieval scholastic cosmology animal coeleste referred to immortal heavenly creatures. Almqvist has tailored its meaning to refer to the moral purity of animals and to emphasize the importance of instinct. Depending on one's interpretation, a "divine creature" may be understood as some kind of external or superior being apart from the existing gender dichotomy. Animalism is exhibited in how Tintomara becomes enchanted with the forests of Kolmården. There "with a smile, she regards the shape of her feet, often putting her two hands next to them to compare" (QD, 80). $3^{\circ}$ Tintomara's transcendental quality is also emphasized by the fact that she has not been baptized. Not only is her gender undetermined; she exists outside the Christian community.

Tintomara represents a person in an instinctive, totally natural state. In a comprehensive study of the novel written in I 9 I9, Henry Olsson underscores Tintomara's proximity to nature, exoticism, and innocence. He sees her as a combination of Rousseauian savage and provincial country girl. She also represents art and theatre in the emotional aspect of her being. Olle Holmberg examined Almqvist's version of animal coeleste, whose innocence is emotional rather than logical. Through their unreflective, spontaneous 
natures, divine creatures can live in harmony with themselves and their surroundings. Almqvist saw Tintomara as an ideal romantic persona - comparable to Schiller's notion of the play instinct as a human perfector - that combined spirituality and animality. ${ }^{3}$

From a queer perspective, the figure of Tintomara explains why other characters in the novel feel erotically and emotionally drawn to a person of their own sex. Amanda and Adolfine fall in love with Tintomara when they think - but are unsure - that she is a man. Ferdinand and Clas Henrik also fall in love, but apparently before they realize Tintomara is "actually" a woman. This is a classic example of a queer thought line. The androgyne sparks a great deal of desire all around. A cross-dressed woman seems to be an especially popular object of desire. Jonathan Dollimore refers to this as "the perverse dynamic." Homosexuality is both an intimidation and an enticement. This bipolar repulsion and fascination is not caused by homosexuality as such, but by the instability of heterosexuality. That the dominant culture defines itself as heterosexual is a basic queer point. Queer, however, is driven into obscurity, cut off, and discarded as a mere fragment of cultural history. ${ }^{32}$

Same-sex eroticism, particularly between two women, has always been characterized by a degree of sexual ambivalence. Martha Vicinus has identified four historical types that are paradigms for modern definitions of lesbian identity:

- A cross-dressing woman or a transvestite character

- A masculine woman who represents female masculinity

- A free and independent woman, in charge of her own sexuality, who engages in sexual relationships with both women and men

- Romantic friendships between women that take on the form of a Sapphic relationship ${ }^{33}$

Tintomara's unique personal charm gives us the impression that her gender is a mix of both "female" and "male." Her allure is based on her fleeting gender flexibility and other models of desire beyond the standard heterosexual cultural matrix. When an object of desire is transformed through a transvestite disguise, the dynamics of gender and desire also change. ${ }^{34}$ 
The dramaturgy of the desire present in The Queen's Diadem is reminiscent of trouser roles in the theatre and opera, where the attraction changes even though the disguise remains intact. Such roles can be divided into three main categories. The first includes former castrato roles in operas that can have multi-gendered casting; the second consists of characters akin to Rosalind in Shakespeare's As You Like It, where the performer is unambiguously female and only cross-dresses as a man; and the third has "male" characters such as Cherubino in Mozart's Le nozze Figaro and Octavian in Strauss's Der Rosenkavalier, both of whom function as young men. The dramaturgy of the trouser roles in the second category dates back to the Renaissance: the female character finds herself in a conflict from which she cannot escape as a female, although she is wise and resourceful. In male disguise she becomes an active figure and sometimes a governing character. However, masculine dress only brings short-lived freedom. Masquerading serves the task of the play, which is usually related to solving one or more conflicts of the heart. When that has been accomplished the disguise is cast off. In comedies, the pairing of one or more heterosexual couples is usually climaxed by a wedding. ${ }^{35}$

The classic masquerade mechanism assumes that a "correct" and "incorrect" gender exists. The correct gender identity is preferably something that is clear to both audience and actors, and so that kind of role-play is comprehensible. The dramaturgical tension is dependent on the divergence between what the audience knows and sees, and what the play's characters think they know and see. A trouser role can also be viewed from a lesbian perspective, in which case the woman in the trouser role does not imitate a man, but instead is shown as actively desiring another woman, or women in general. Contrary to the conventional "correct" interpretation, a cross-dressed character problematizes the "natural" arrangement in which desire is inexorably fixed on a body of the opposite gender.

\section{Tintomara: The five-leaf clover and object of desire}

When the five of hearts or five of spades is used as a structural symbol in The Queen's Diadem, Tintomara is at the center - the ace. As the young aristocrats begin a game of cards, the ace of 
hearts is missing from the deck and another card is in its place. Ferdinand takes the five of hearts and scrapes the small hearts from its corners, so that a single heart remains in the center. The novel plays with different configurations of cards: a four can become a five if a heart is added or a five can become a four if a heart is removed. A five can become a one if all the hearts are taken from the corners.

Tintomara was placed on the floor among her enemies, and four guards, chosen pupils, were placed around her in a square. Adolfine, watching the group from a distance from a bench on which she had climbed, smiled at the expressive representation of a five of spades; the savage woman herself in the middle with two young men over her outstretched hands and two young girls over her feet, all on top of a white carpet spread under them, truly made a picture which resembled this ominous card.

The music started, and at a sharp fortissimo Tintomara made a movement, a gesture with her hands and feet, so elastic but also so strong that all four guards bounced far away from her on the floor. On the instant, she was up and in flight. (QD, 68) ${ }^{36}$

Tintomara in the middle as the ace of hearts is desire itself, but her love is unattainable. Almqvist seems to want to depict the dissonance between undefined gender and unattainability, and also between structure and order. The setup is emphasized by the young aristocrats each having their own vocal register - bass, tenor, alto, and soprano - whereas Tintomara's register is more difficult to pinpoint in terms of gender: "A kind of alto, which would sometimes move into the range of the soprano, other times verging on a proper tenor voice" (QD, 4 I). ${ }^{37}$ Each of the four has their own occupation to pass the time while hiding in Östergötland: hunting, playing the violin, singing, and reading aloud. Tintomara takes part in all of these activities.

The youths infatuated with Tintomara soon become competitors in the typical Western romantic form of a triangle. The story turns out to be one of how a lover triumphs over all others and claims the beloved - or tragically fails in the attempt. ${ }^{38}$ Claiming the beloved always entails overcoming obstacles. René Girard highlights the centrality of competition in romantic narratives of love in his study Deceit, Desire, and the Novel: Self and Other in 
Literary Structure. ${ }^{39}$ He sees the phenomenon as a triangle driven by a mimetic desire, namely, the wish to ignite one's competitors more than pursue the love interest. Thus, such love is not shown in a straightforward fashion but as a triangle. Someone loves someone else who is loved by a third person, that is, an individual becomes desirable because of the desire of a third individual.

Although Girard mainly examines heterosexual desire, he alludes to same-sex desire in a passage assessing Marcel Proust. In Between Men, Eve Kosofsky Sedgwick suggests that English literature since Shakespeare has been structured according to an erotic triangle governed by homosocial desire between men. ${ }^{40}$ According to Sedgwick, the homosocial triangle is so evident that a consensus between male characters is an essential part of the triangle which, in literature is founded by two men and one woman, whereby the man's true object of desire is not the woman, but the other man.

An uncertain dynamic is present between homosocial desire and homosexuality. Sedgwick states that the homosocial desire governing the triangle creates a strong bond between the men, but if that bond proves too tense (i.e., openly homosexual), the men face ideological resistance. If a man takes on the "female" role in homosexual intercourse, how can he then be differentiated from a woman? The eroticization of the bond between the men thus compromises the perception of the patriarchal gender divide between men and women.

Ferdinand and Clas Henrik invite Tintomara to their cabin in Kolmården, an unambiguously homosocial environment in which they go fishing and hunting, play cards, and walk around unshaven. Both men fall hopelessly in love with Tintomara, but only after finding out they share the secret of Tintomara's gender. Nevertheless, their relationship is equivocal. While they are hanging around the cabin longing for Tintomara, Ferdinand says to Clas Henrik: "Why shouldn't a promising young man be amusing to associate with? I confess it honestly - good, clever, lively male companionship - that's something I've always liked" (QD, I 50).4I

Male characters in narrative fiction are routinely complimented on each other's beauty and virtues, and may even describe their mutual relationship as one of love, without the reader associating it with eroticism. But references to the homoeroticism of the 
Symposium and mention of the rumors about Gustav III prevent a totally heterosexual reading of the relationship between Ferdinand and Clas Henrik. The reader is left to interpret the ambiguity.

Terry Castle assesses Girard and Sedgwick's triangular models in The Apparitional Lesbian and offers an alternative: the lesbian counterplot. ${ }^{42}$ Castle extends Sedgwick's model to reflect a relationship of desire between two women, posing the question of what happens to the triangle when the circumstances are broadened and another woman enters the picture. She argues that in this new arrangement a homosocial structure between the two women arises and greatly marginalizes the rapport between the men involved. In Castle's model, men can become just as isolated as women in Sedgwick's triangular model. For Castle the homosocial desire between women may be as dynamic as between men, even - at its most radical - to the extent of becoming one of lesbian desire. Borrowing two terms from Nancy C. Miller, Castle describes a plot as dysphoric if it has a heterosexual conclusion, and euphoric if it has a lesbian one. The lesbian counterplot thus challenges the standard heteronormative narrative. ${ }^{43}$

Adolfine, the first of the four young people who encounter Tintomara, moves freely about town and in society, even attending a masquerade ball unescorted. It is there that she meets Tintomara and clearly perceives her as a woman. The encounter takes place after the murder of the king. In the narrative Adolfine has just climbed onto the stage of the theatre and comically steps into a dreamlike world. Tintomara is in the costume that Adolfine had first thought of wearing and so Adolfine initially mistakes Tintomara for her own reflection. When Tintomara asks for her help in changing clothes, Adolfine - and the reader - can study the incredibly beautiful Tintomara. As if hit by lightning, Adolfine is lovestruck.

Adolfine approached with a secret smile at this familiar request and unhooked the dress. She experienced a strange feeling - but we are both female, she thought, and it does not matter! - Still, she experienced a strange emotion when, in a series of quick, beautiful turnings, not just the belt, but the whole orange dress (the laced corselet was allowed to remain, untouched up to the neck), the lawn sleeves, shoes and purple stockings: everything disappeared from the figure $(\mathrm{QD}, 64)^{44}$ 
Adolfine's gaze is erotic; she continues to stare at Tintomara's beautiful figure, as it is stripped of its garments one by one. The novel depicts the encounter between Adolfine and Tintomara in far more detail than other relationships based on desire. Tintomara is only portrayed as an active temptress in her tryst with Adolfine. Her encounters with potential male love interests are far less explicit.

Although Adolfine tries to compose herself by recalling that they are both women, she sees that Tintomara's beauty far exceeds her own. Standing in such close proximity to Adolfine, Tintomara becomes an overwhelming erotic object of desire. Adolfine, thinking to herself, tries to come to terms with the idea of a love between two women:

In a sisterly fashion, she wound her arm around its [Tintomara] black waist; and when Azouras did not refrain from putting her white arm around Adolfine's shoulders, Adolfine felt both warmth and protection from the embrace. Certain sympathies are mysterious and incomprehensible. (QD, 7I) ${ }^{45}$

We wonder if the adjectives "mysterious" and "incomprehensible" are Adolfine's or the narrator's. The rules of propriety in same-sex relationships at the time precluded a woman from admitting that she felt warmth and a sense of security in another woman. Women were only to experience that with men.

Adolfine kept the white hand in hers and, at the start, had difficulty finding words for what she meant: - All the way from the shoulder down to your finger tips .... white, quite white .... she said. - Yes, I believe there is much in you that is lovable .... whoever you are, listen to some advice from me. You're in strange company up there; I mean .... ugly practices .... a girl like you .... you feel .... you should feel it, as well as I . . . avoid the gestures of those people when they speak of . . . of love . . . beware of love. Adolfine inclined her head. She didn't understand how she had come to speak in this vein. (QD, 7I-72) $)^{46}$

As Adolfine recalls the wondrous evening at the opera, her heart skips a beat and she rejoices: "I'm allowed to love a girl!" (QD, I43). When Tintomara then says she was only dressed as a girl, Adolfine is startled, and tries to reassure herself that her infatuation 
was pure and innocent. Later as everything comes crashing down and the two sisters argue bitterly, Adolfine accuses Amanda of lying when she claimed her relationship with Tintomara was nothing more than a friendship. As Eva Borgström points out, the same can be said for Adolfine herself. ${ }^{47}$

\section{The transient nature of desire}

Girard, Sedgwick, and Castle all find the triangular model inadequate because it prioritizes the couple. The triangle model is based on dualistic thinking and it is confirmed each time another member enters. According to Marjorie Garber, the triangular model is untenable in itself. When bisexuality is added to the equation, the triangle is eroticized and results in the seduction scenario. The triangular structure incorporates bisexuality as one of its aspects. While bisexuality is equally directed towards two genders, multisexuality is a more open category. Flexible erotic displacement and the play of sexual possibilities make Tintomara a multisexual character. She can move in both heterosexual and homosexual contexts with equal freedom. Tintomara thus represents both multi-sexuality and androgyny. ${ }^{48}$

Androgyny is often associated with multi-sexuality and has figured importantly in Shakespearean study, where it has sparked two lines of discourse. The first draws on ambiguous characters who cross-dress, such as Rosalind/Ganymede and Viola/Cesario. As androgynous figures they combine femininity and masculinity, and become objects of desire for both women and men. The second line of discourse pertains to Shakespeare's androgynous world of theatre. Already in I664, Margaret Cavendish wrote of Shakespeare's ability to empathize with both female and male thought and emotion. Later, Coleridge and other romantics discussed Shakespeare's androgynous spirit. One is reminded of Virginia Woolf's laconic comment in A Room of One's Own that androgyny of the mind is the source of all creativity. Woolf views Shakespeare as an example of such androgynous thinking, although she concedes that it is impossible to know what Shakespeare really thought about women.49

The cross-dressing and androgynous Tintomara represents restlessness, variability, quick-wittedness, and uniqueness. She sets 
her surroundings, including the triangles of desire, in motion. In Tintomara's case, the casting off of a disguise does not signal a return to the prevailing modes of gender and desire. J. Jack Halberstam states in Female Masculinity that the androgyne "represents a different form of gender variance than the masculine woman, and although the androgyne may have faced some kind of social opprobrium, it probably did not come in the form of a response to gender confusion." ${ }_{50}$ According to Halberstam the androgyne represents some version of gender mixing, but this rarely adds up to total ambiguity.

In The Queen's Diadem, Tintomara's character raises questions about the external and internal dynamics between and within the sexes. She unmistakably shows that a person is neither of a specific, preordained, uncompromising gender, nor a clearly defined sexual being. Instead, a variety of factors mold people into heterosexual women and men. Tintomara personifies one way in which femininity and masculinity may be constructed. Almqvist's novel does not follow the logic of feminine $=$ womanly $=$ female , and masculine $=$ manly = male. Instead, his differentiation of female, womanly, and feminine, and also of male, manly, and masculine, is surprisingly close to our contemporary perspective on gender and queer thinking, according to which these concepts are not synonymous.

On a more general level, femininity and masculinity refer to social statuses, whereas female and male are anatomical categories. Femininity embodied in a biological woman, like masculinity in a man's body, can be simultaneously true of the same person, although not necessarily. There are many types of women and femininities, as there are also many types of men and masculinities. Queer theory has taken the lead in criticizing the notion that there is only one, socially acceptable, uniform line of either femininity or masculinity that applies to every woman and man.

Tintomara's androgyny can be decoded as a continuously renewed attack against the social pressure for erotic certainties. Tintomara's person piques interest in the variations of gender on the one hand, and in the transient nature of desire on the other. She is positioned as a queer subject who questions the models of biological and hegemonic thought. Perhaps the instability of norms is most apparent when femininity is not automatically associated 
with a female body, or similarly when a male body does not necessarily represent masculinity.

Tintomara's death is no dysphoric solution or dramaturgical return to order. Lars Burman argues that alongside romantic aesthetics, The Queen's Diadem is a counterweight that embodies social criticism and an undercurrent of rebellion. It is often overlooked that near the end of the novel, Tintomara - who chooses to remain an external figure in love, gender, and class dynamics - leaves lady-in-waiting Madeleine Rudensköld an assignment. She asks her to "remember the task," which according to Burman is the banishing of the conspirator Reuterholm. ${ }^{{ }^{\mathrm{I}}}$ Tintomara is far more than a flighty child of nature, a peculiar androgyne living on her instincts, or a societal outsider, s/he is also the driving force behind rebellion and social change.

\section{Notes}

I. The abbreviation “QD” stands for The Queen's Diadem in English; "DJ" refers to the Swedish original, Drottningens juvelsmycke. "Mig finner ingen, // Ingen jag finner. /.../ Jag ler åt alla, // Alla åt mig le. Tintomaras sång.” (DJ, I7I)

2.Although Tintomara's gender remains unclear, since the novel uses "she" to refer to her, we will continue that here.

3. See, for example, Doty, Making Things Perfectly Queer; Rosenberg, Byxbegär; Queerfeministisk agenda, I I7.

4. This slight modification of Alexander Doty's definition of queer admits trans-identities into queer. See Doty, Flaming Classics, 6; Hall \& Jagose, The Routledge Queer Studies Reader.

5. Westman Berg, Studier. See a review of her study in Bertil Romberg's "Almqvistsforskning." An extensive editor's introduction to DJ by Lars Burman may be found in the 2002 Swedish reprint of Drottningens juvelsmycke.

6. Hagedorn Thomsen, “Androgyneproblemet II”; Mortenson, “Till Tintomaramotivets historia." The essay was later published in an expanded form as "Tintomara" in Mortensen, Människor och böker. See also Holmberg, "Introduction.”

7.Adolfsson, "Det androgyna skapandet." 


\section{Cavallin, “Androgynens kön.”}

9. Desertrain, “A Study of Love"; Borgström, "Musikens och erotikens harmonilära," I44.

Io. "Visserligen måste det vara något eget ändå med denna varelse. Halsens och bröstets början, som jag såg, voro af en mycket behaglig, men underbar struktur, som syntes tillåta, att den förra stundom skulle höjas, jemte det senares sammandragning eller förhårdning; och tvertom, vid andra tillfällen, det sednare litet vidgas, jemte hela figurens förminskning." (DJ, 5I) See also Borgström, "Musikens och erotikens harmonilära," I46.

I I. "Den undersökta sägs ha försökt värja sig dels 'med det smekan$\mathrm{da}$, ytterst intagande uttrycket af en lidande siren', dels 'med spotsk stolthet', som 'nästan kunde tyckas manligt.'” (DJ, 5I)

I 2. Ibid.

I3. Ibid.

I4. Plato, Om kärleken och döden. See also the comments of translator Robin Waterfield to Plato, Symposium.

I 5 . Borgström, “Musikens och erotikens harmonilära,” I 44 .

I6. Used in a derogatory sense, "androgyne" means "cowardly": a man who does not meet contemporary expectations of masculinity.

I7. DJ, 54 .

I 8. "Med androgyn förstod man något besynnerligt, ja, mystiskt. Man har trott, se ni, - och man hade flere skäl för denna tro - att menniskan ursprungligen blott skapades till menniska. Icke man, och ej kvinna, utan rätt och slätt människa; förstår ni min vän? Jag vet likväl icke, om med Androgyn bör förstås en varelse, som är ingetdera könet, eller beggedera. Det förra synes ytterst melankoliskt; på det sednare, åter, hava de gamle mycket tänkt. Det vore nämligen i det senare fallet, min vän, en Helhet, som i ett väsende förenade bägges arter /.../ De gamle, som med androgyn tänkte sig ett fullkomligt, själv-tillräckligt, i deras tanke gudasällt väsende, tillade, att det var just menniskans fall, eller åtminstone en integrerande del av fallet, då menniskoväsendet klövs itu, föll sönder i tvenne kön, vilkas öde skulle bli, att till ve och väl jaga varann oupphörligt. Genom den ursprungligen eviga menniskovarelsens söndrande, så att den i stället 
för en sfär blev tvenne hemisfärer, två slags varelser, man och kvinna; därigenom, min vän, uppkom väl möjligheten av kärlek (Eros), men också av tvist (Eris).” (DJ, 52-53)

I9. As cited in Borgström, "Musikens och erotikens harmonilära." She is referring to Page du Bois's Sappho Is Burning: "It [women's erotic life with other women] is allowed for as a matter of symmetry, but it is the redundant third term, male-female sex leads to reproduction, male-male sex demonstrates virility, female-female sex is not characterized," 9I.

20. "Lova mig Georg, att åtminstone du icke älskar mig? /.../ Alla andra älska mig, vissna, dö, förgås, gå sönder.” (DJ, 263)

2I. Borgström, “Musikens och erotikens harmonilära,” 99, I48.

22. Butler, Psychic Life of Power, I39-I40.

23. Ibid.

24. For C.J.L. Almqvist's theatre traits, see Lagerroth, "Almqvist och scenkonsten"; "Amorina och Tintomara på Dramaten"; "Konsten är det enda fullt uppriktiga"; "Melodramteatern som kod"; "Selma Lagerlöf och teatern.”

25. Garber, Vested Interests, 256.

26. Svedjedal, Almqvist, 26, 29, 45, 67.

27. “Tintomaras röst tvärstannade och huvudet hajade åt sidan, ty hennes skarpa syn tycktes märka, att något verkligen nalkades, och det var som om alla de, av vilka hon i sin sjungande fantasi tog avsked, kommod för att taga avsked av henne, även de. Hon såg det röra sig på de fyra vägarne: hon såg det röra sig fram emot henne ur det avlägsna svarta fjärran på en gång i alla fyra vägarne. Det nalkades avmätt, tyst, men lika i alla de svarta långa öppningarne. Det nalkades i varje av dem så försiktigt, som om varje på sitt håll icke vill vara bemärkt av någonting annat.” (DJ, 2 I8) See also Burman, "Introduction," ix.

28. Lehnert Maskeraden und Metamorphosen, 6; Wenn Frauen Männerkleider tragen.

29. "Det djuriska sättet att vara, instinktlivet, visar den harmoniskt intagande bilden av en hög enighet med sig själv. Ni har väl hört mystikernas tanke om animal celeste. Människans strävanden, påstår 
man, skall verkligen vara, att till slut bliva natur igen, att bliva liksom ett djur." (DJ, 53)

30. "Hon roade sig med det hon vid sådana tillfällen ofta brukade, nämligen att sätta sina händer bredvid fötterna och så jämföra dem alla fyra." (DJ, I69)

3I. Olsson, "C.J.L. Almqvist"; Holmberg, "Introduction," v-xv; Burman, "Introduction," xxii.

32. Dollimore, Sexual Dissidence.

33. Vicinus, “They Wonder to Which Sex,” 436-439.

34. In the theatre, the term for disguise is travestia. This concept refers first to disguising oneself, second to ridiculing, distorting, twisting or parodying, and only third to dressing up as the opposite sex. Both the French en travesti and the Italian travestire mean to disguise oneself and derive from the Latin trans (across) + vestire (to clothe). The English term "cross-dressing" is, therefore, its equivalent and is generally applied to men dressing in women's clothing or women in men's clothing. Theatre scholar Live Hov, who has studied the significance of travestia in theatre, uses the term den grundläggande travestin (the basic travesty) in her doctoral dissertation "Kvinnerollene i antikkens teater." Regarding trouser roles, see Rosenberg, "Transvestism och maskerad"; Byxbegär; "Om heteronormativ historieskrivning"; Senelick, Gender in Performance; The Changing Room. See also Blackmer \& Smith, En Travesti; Hadlock, "The Career of Cherubino, or The Trouser Role Grows Up"; André Voicing Gender; Listening to the Siren. The above are all examples of a continued interest in trouser roles and queer performance.

35. Dutch historians Rudolf Dekker and Lotte van de Pol claim to have found only one example of socially acceptable female transvestism in the secluded mountain region of Northern Albania, along the border between Kosovo and Montenegro. The area was inhabited well into the twentieth century by a group of mountain people whose culture was characterized by internal contradictions and a steep hierarchy with regard to men and women. Despite this, a woman could decide to take an oath of virginity and remain unmarried. Such a woman then dressed in men's clothing, possibly even bore arms, and in effect attained a position equal to that of a man.

The best-known example of a transvestite in European theatre and literature (especially "chick lit") is probably Rosalind in As You 
Like It. She is an archetypical tomboy who has inspired many similar characters in cinema. See also Rosenberg, Byxbegär.

36. "Tintomara lades på golvet midt ibland sina fiender, och fyra väktare, utvalde elever, sattes omkring henne i en fyrkant. Adolfine, som såg gruppen på afstånd ifrån en bänk där hon uppstigit, log verkligen åt den uttrycksfulla bilden av en spaderfemma; ty den vilda sjelf i midten med sina två ynglingar öfver de utsträckta händerna, och sina två flickor över fötterna, alltsammans ofvanpå en vit matta utbredd under dem, gjorde i sanningen en tafla som liknade detta ominösa kort.

"Musiken började, och vid ett skarpt fortissimo gjorde Tintomara en rörelse, en sprittning så elastisk, men tillika stark, med händer och fötter, att alla de fyra väktare studsade långt undan ifrån henne på golvet. I ögonblicket var hon uppe och flydde.” (DJ, 84)

37. "En slags alt, som ena gången gick in på Sopranens område, andra gången gränsade till en ordentlig Tenor.” (DJ, $5 \mathrm{I}$ )

38. Girard, Deceit, I7.

39. Ibid.

40. Sedgwick, Between Men, 26, 86.

4I. "Varför skulle icke en hoppingivande yngling vara rolig att umgås med? Det känner jag helt uppriktigt-ett gott, raskt, livligt karlsällskapdet har jag alltid tyckt om.” (DJ, I92)

42. Castle, The Apparitional Lesbian, 66-9 I.

43. "Dysphoric" refers to a melancholic disposition, and its polar opposite, "euphoric", to exhilaration.

44. "Adolfine nalkades med hemligt leende över denna förtroliga anhållan, och spände upp klänningen. Hon erfor en besynnerlig känsla men vi äro bägge fruntimmer, tänkte hon, och det gör ingenting! - en besynnerlig rörelse erfor hon likväl, när under hastiga vackra vändningar ej blott skärpet, men hela orangeklänningen (snörlivet fick bli orört kvar ända upp till halsen), lingonsärmarne, skor och purpurstrumpor, alltsammans försvann från gestalten.” (DJ, 79)

45. "Systerligt lindade hon sin arm om dess svarta lif; och när Azouras icke försmådde att också lägga sin hvita arm kring hennes axlar, så tyckte Adolfine sig finna både värme och ett värn härifrån. Vissa sympatier äro hemlighetsfulla och oförklarliga.” (DJ, 87) 
46. "Adolfine kvarhöll den hvita handen, och hon hade i början svårt att finna ord för vad hon menade: 'Ända ifrån axeln ner till fingerspetsarna - hvitt, ganska hvitt' - sade hon - 'ja, jag tror att hos dig är mycket älskvärt - vem du är, hör också på ett råd från mig. Du är uti ett besynnerligt sällskap däruppe; jag menar - fula seder - en flicka som dy - du känner - du bör känna det, såväl som jag - undvik det där folkets gester, när de tala om. . . kärlek - akta dig för kärlek -' Adolfine lutade sitt hufvud, hon förstod icke själv hur hon kommit att tala åt detta håll.” (DJ, 88)

47. Borgström, "En musikens och erotikens harmonilära," I 62.

48. Garber, Vested Interests, $43 \mathrm{I}$.

49. Woolf, A Room of One's Own, 94.

50. Halberstam, Female Masculinity, 57.

5 I. Burman, "Introduction," viii.

\section{Works Cited}

Adolfsson, Eva. "Det androgyna skapandet - en Almqvistsläsning" ("The Creation of the Androgyne - an Almqvist Reading"). In I gränsland. Essäer om kvinnliga författarskap, I 54-I88. Stockholm: Bonnier, I99I.

Almqvist, Carl Jonas Love. Drottningens juvelsmycke (DJ). In Törnrosens bok, Duodesupplagan, Band IV, edited and annotated by Lars Burman. Stockholm: Svenska Vitterhetssamfundet, 2002 [I 834].

Almqvist, Carl Jonas Love. The Queen's Diadem (QD). Drottningens juvelsmycke, translated by Yvonne L. Sandstroem. Columbia, SC: Camden House, I992 (I 834).

André, Naomi. Voicing Gender: Castrati, Travesti, and the Second Woman in Early Nineteenth-Century Italian Opera. Bloomington: Indiana University Press, 2006.

Blackmer, Corinne E. and Patricia Juliana Smith, eds. En Travesti: Women, Gender Subversion, Opera. New York: Columbia University Press, I995.

Borgström, Eva. "En musikens och erotikens harmonilära eller Hur många kön finns det i Almqvists 'Drottningens juvelsmycke?”” (“A 
Musical and Erotic Theory of Harmony; or How many Genders are There in Almqvist's 'The Queen's Diadem'?"). Res Publica 43 (I999): I43-I67.

Burman, Lars. "Introduction” to Törnrosens bok. Duodesupplagan, Band IV: Drottningens juvelsmycke by Carl Jonas Love Almqvist, edited and annotated by Lars Burman, vii-xxxv. Stockholm: Svenska Vitterhetssamfundet, 2002 [I 834].

Butler, Judith. The Psychic Life of Power: Theories in Subjection. Palo Alto: Stanford University Press, 1997.

Castle, Terry. The Apparitional Lesbian: Female Homosexuality and Modern Culture. New York: Columbia University Press, I993.

Cavallin, Anna. "Androgynens kön - en feministisk läsning av C. J. L. Almqvists 'Drottningens juvelsmycke" ("The Gender of the Androgyne - a Feminist Reading of 'The Queen's Diadem' by C. J. L. Almqvist). Tidskrift för litteraturvetenskap I (I998): 3-23.

Dekker, Rudolf, and van de Pol, Lotte. Kvinnor $i$ manskläder. En avvikande tradition Europa I 500-I800 (The Tradition of Female Transvestism in Early Modern Europe). Stockholm: Symposion, I995.

Desertrain, Laura Margaret. "A Study of Love. C.J.L. Almqvist's Drottningens juvelsmycke." Doctoral dissertation, University of Wisconsin-Madison, I982.

Dollimore, Jonathan. Sexual Dissidence: Augustine to Wilde, Freud to Foucault. Oxford: Clarendon Press, I99I.

Doty, Alexander. Making Things Perfectly Queer: Interpreting Mass Culture. Minneapolis: University of Minnesota Press, I993.

. Flaming Classics: Queering the Film Canon. New York: Routledge, 2000.

du Bois, Page. Sappho is Burning. Chicago: University of Chicago Press, I995.

Garber, Marjorie. Vested Interests: Cross-Dressing and Cultural Anxiety. New York: Routledge, I995.

Girard, René. Deceit, Desire, and the Novel: Self and Other in Literary Structure (Mensonge romantique et vérité ramanesque). 
Translated from the French by Yvonne Freccero. Baltimore: Johns Hopkins University Press, I990 [I961].

Hadlock, Heather. "The Career of Cherubino, or The Trouser Role Grows Up." In Siren Songs. Representations of Gender and Sexuality in Opera, edited by Mary Ann Smart, 67-92. Princeton: Princeton University Press. 2000.

Hagedorn Thomsen, Hans. "Androgyneproblemet II" (The Problem of the Androgyne II). Kritik. Tidsskrift for litteratur, forskning, undervisning I 5 (I970): 9I-I I 8.

Halberstam, Judith (J. Jack). Female Masculinity. Durham, NC: Duke University Press, I998.

Hall, Donald E., and AnnaMaria Jagose, eds. The Routledge Queer Studies Reader. New York: Routledge, 20I 2.

Holmberg, Olle. "Introduction” to Törnrosens bok. Band IV, by Carl Jonas Love Almqvist. Stockholm: Bonnier, I92 I.

Hov, Live. "Kvinnerollene i antikkens teater - skrevet, spilt og sett av menn" (Women's Roles in Ancient Theatre - Written, Played, and Viewed by Men). Doctoral dissertation, University of Oslo, I998.

Lagerroth, Ulla-Britta. "Almqvist och scenkonsten" (Almqvist and the Performing Arts). In Perspektiv på Almqvist, edited by Ulla-Britta Lagerroth and Bertil Romberg, 217-298. Stockholm: Rabén \& Sjögren, I973.

. "Amorina och Tintomara på Dramaten. Två samtal med Alf Sjöberg" (Amorina and Tintomara at the Royal Dramatic Theatre. Two Encounters with Alf Sjöberg). In Perspektiv på Almqvist, edited by Ulla-Britta Lagerroth and Bertil Romberg, 299-322. Stockholm: Rabén \& Sjögren, I973. lan konstarter och mellan konst och liv" ("Art is the Only Fully Sincere. Almqvist Between Art Forms, and Between Art and Death"). In I lärdomens trädgård. Festskrift till Louise Vinge, edited by Christina Sjöblad, Mona Sandqvist, Birthe Sjöberg, and Johan Stenström, I09-I25. Lund: Lund University Press, I996.

dramaturgi" ("Melodrama as a Code in Almqvist's Narrative 
Dramaturgy"). Aiolos, tidskrift för litteratur, teori och estetik, Special edition: Slöja och spegel - romantikens former I4-I 5 (2000a): 53-78.

. "Selma Lagerlöf och teatern" (Selma Lagerlöf and the Theatre). In Vetenskapssocieteten i Lund Årsbok I999/200o, 93I I3. Lund: Vetenskapssocieteten i Lund, 200ob.

Lehnert, Gertrud. Maskeraden und Metamorphosen. Als Männer verkleidete Frauen in der Literatur. Würzburg: Köningshausen \& Neumann, I994.

Menn Franen Mannerkleider tragen. Geschlecht und Maskerade in Literatur und Geschichte. Munich: Deutscher Taschenbuchverlag, I997.

Mortensen, Johan. "Till Tintomaramotivets historia" (On the History of Tintomara). In Studier tillägnade Henrik Schück på hans 50 årsdag den 2 november 1905 af vänner och lärjungar, edited by Oscar Levertin and Henrik Schück, 268-278. Stockholm: Geber, I905.

. Människor och böcker. Studier och kritiker (People and Books. Studies and Critics). Lund: Gleerups, I9I7.

Olsson, Henry. “C. J. L. Almqvist, 'Drottningens juvelsmycke.' En diktmonografi och en orientering” ( “C. J. L. Almqvist, 'The Queens Diadem.' A Poet Monograph and a Guide”). Samlaren 40 (I9I9): $85-\mathrm{I} 72$.

Peraino, Judith A. Listening to the Sirens: Musical Technologies of Queer Identity from Homer to Hedwig. Berkeley: University of California Press, 2006.

Plato. Symposium. Translated by Robin Waterfield. Oxford: Oxford University Press, I994.

Romberg, Bertil. “Almqvistsforskning I869-1966” (Research on Almqvist I 869-I 966). Svensk litteraturtidskrift 4 (I966): I 57-I 87.

Rosenberg, Tiina. “Transvestism och maskerad. Några nedslag i feministisk teater och teori" ("Transvestism and Masquerade. On Feminist Theatre and Theory"). In Svenska teaterhändelser I946I 996, edited by Lena Hammergren, Karin Helander, and Willmar Sauter, 330-352. Stockholm: Natur och Kultur, 1996.

. Byxbegär (Desiring Pants). Göteborg: Anamma, 2000. 

normative History”). In Makalösa kvinnor: könsöverskridare i myt och verklighet, edited by Eva Borgström, 239-284. Gothenburg: Alfabeta/Anamma, 2002a.

Stockholm: Atlas, 2002b.

Sedgwick, Eve Kosofsky. Between Men: English Literature and Male Homosocial Desire. New York: Columbia University Press, I985.

Senelick, Laurence. Gender in Performance: The Presentation of Difference in the Performing Arts. Hanover, NH: University Press of New England, I992.

\section{Routledge, 2000.}

Smart, Mary Ann, ed. Siren Songs. Representations of Gender and Sexuality in Opera. Princeton: Princeton University Press. 2000.

Svedjedal, Johan. Almqvist-berättaren på bokmarknaden (Almqvistthe Narrator in the Book Market”). Uppsala: Almqvist \& Wiksell, I 987 .

Vicinus, Martha. "'They Wonder To Which Sex I Belong': The Historical Roots of the Modern Lesbian Identity." In The Lesbian and Gay Studies Reader, edited by Henry Abelove, Michèle Aina Barale, and David Halperin, 432-452. New York: Routledge, I993.

Westman Berg, Karin. Studier $i$ C. L. J. Almqvists kvinnouppfattning (Studies in C. L. J. Almqvist's Discourse on Women”). Gothenburg: Akademiförlag, I962.

Woolf, Virginia. A Room of One's Own. London: Granada Publishing, I977 [I929]. 